\title{
La Madraza Yūsufiyya en época andalusí: un diálogo entre las fuentes árabes escritas y arqueológicas
}

\author{
The madrasa Yusufiyya in al-Andalus time: a dialogue between archeological \\ and written arabic sources
}

Bilal J.J. Sarr Marroco *; Luca Mattei *

\begin{abstract}
RESUMEN
En este artículo se pretende ofrecer un análisis de la única madraza pública de al-Andalus cuyos restos han persistido hasta el momento. Para ello se ha tratado de establecer un diálogo entre las fuentes escritas y los hallazgos arqueológicos que nos ha brindado especialmente la última intervención del 2006.
\end{abstract}

Palabras clave: Madraza, nazarí,Yūsuf I, siglo XIV, Riḍwān.

\section{INTRODUCCIÓN}

El Palacio de la Madraza, conocido también como Casa del Cabildo o Cabildo Viejo de Granada, es uno de los edificios más emblemáticos de la ciudad de Granada que nos ha llegado del periodo nașrī. Éste representa el único ejemplar de madraza pública que ha existido en la Península Ibérica.

En este artículo pretendemos actualizar los conocimientos sobre la Madrasa Yūsufiyya, estableciendo una relación entre los datos que nos aportan las diferentes referencias que se hallan en las fuentes árabes escritas y las conclusiones extraídas del registro arqueológico, sobre todo a raíz de la intervención arqueológica del año 2006, dirigida por Antonio Malpica Cuello en el marco de un proyecto tutelado por la Universidad de Granada para la rehabilitación del edificio (Fig. I).

\begin{abstract}
In this article we try to offer an analysis of the only public madrasa of al-Andalus whose remains have persisted up to the moment. For this, we have tried to establish a dialogue between the written sources and the archaeological findings that specifically the last intervention has offered us.
\end{abstract}

Key Words: Madrasa, nașrid, Yūssuf I, I4th century, Riḍwān.

De esta forma, se ha intentado trazar no sólo la historia constructiva del edificio, poniendo en relación los vestigios que se hallaban en superficie con los que se exhumaron, sino también explicar sus orígenes, evolución y papel en el mundo nazarí.

Por otro lado, debemos precisar que la intervención que nos ocupa en este trabajo no ha sido la única que se ha acometido hasta el momento; se han desarrollado otras anteriores en época moderna y contemporánea que nos han servido de punto de partida, y para establecer el estado de la cuestión (CRUZ CABRERA et alii, 2007:43-159). De hecho, tenemos constancia de una actuación realizada a finales del siglo XIX que tuvo por objeto la restauración del actual oratorio de la Madraza, que fue financiada por la familia Echeverría, propietaria del inmueble, y ejecutada por el conservador y restaurador Mariano Contreras. Esta actividad la tenemos

* Universidad de Granada 
documentada gracias a unas fotos de la época', en las que se aprecia una estructura de andamiaje en el interior del oratorio, que permitió la consolidación y, en la mayoría de los casos, la sustitución de buena parte de las yeserías que se habían descubierto al realizarse una obra en las paredes de la sala. El reemplazo de la mayoría de las yeserías ha sido también confirmado por un estudio científico de las mismas (GARCÍA BUENO et alii, 2007: 277-304).

Otra reforma menor que ha proporcionado informaciones relevantes tuvo lugar a mediados del siglo XIX, siendo el edificio aún propiedad del Ayuntamiento, en la que se descubrieron unas losas de mármol con inscripciones árabes (Lám. I) que habían sido empleadas como baldosas (GÓMEZ-MORENO GONZÁLEZ, 1982: 309-310 y PAULA VALLADAR, 1890: 231). Éstas que pertenecían a los restos de la puerta de entrada de la Madraza, fueron adquiridas por el señor Facundo Riaño, quien después las donó al Museo Arqueológico y Etnológico de Granada, donde hoy están preservadas y expuestas. Dicho hallazgo resultó de gran importancia ya que brindó la posibilidad de reconstruir parte de la portada que rodeaba el acceso a la misma (Lám. 2).

\section{Contexto histórico}

La Madraza granadina se erige en el periodo de máximo esplendor político, económico, cultural y el de mayor fervor edilicio de la dinastía nazarí. Sólo en esta época, de cierta estabilidad política y de amplios espacios de tiempo de relativa paz en los que incluso se dejó de pagar parias a Castilla, se pueden llevar a cabo, por una parte, las construcciones más destacadas de la Alhambra y de la medina, y por otra el fortalecimiento de las instituciones y de la administración. A todo esto se une el florecimiento de las actividades industriales y mercantiles, con la exportación de la seda, las manufacturas artesanas e incluso la cerámica vidriada de alta calidad.
El sultán bajo cuya égida se construye este insigne edificio es Yūsuf b. Ismāîl b. Faraŷ b. Ismā'îl b. Yūsuf b. Nașr al-Anșārī al-Jazraŷī de kunya Abū-I-Hâŷ̄âŷ (I333-I354) (Al-Lamha, 102 y Reyes, I I I). Éste, conocido como Yūsuf I por la historiografía, subió al poder con sólo I5 años, tras el asesinato de su hermano Muhammad IV, por lo que el visir Riḍwān, sobre el que hablaremos infra, tendrá que ejercer de regente. Contamos con la semblanza que realizó Ibn al-Jațîb sobre este sultán en su Lamḥa al-Badriyya:

"Fue la luna llena de los reyes y el ornato de los príncipes. Tenía la tez blanca y luminosa; era fuerte, de buen talle, hermosa figura, brillantes dientes, ojos grandes, cabellos lacios y negros y espesa barba; de cara bella, agradable conversación y gran dulzura [...] Era muy inteligente [...] Era hábil y profundo" (Lamha, I02/ Reyes, III).

"[...] Predominó en sus días la tregua, la paz y el bienestar. Mantuvo buenas relaciones con el sultán Abū l-Hasan durante los buenos tiempos de éste. Se concertó la paz sin estipulación de tributo (darïba), por un cierto tiempo, cosa que no ha sido frecuente." (Lamha, I09 / Reyes, I20).

Su acción política va encaminada a fortalecer su autoridad a través de las diferentes vías de las que dispuso. Así, en cuanto a la administración, la primera medida que adoptó en esta dirección fue la expulsión de los Banū-I-'Ulà, grupo díscolo que asesinó a su hermano Muhammad IV, y después de ello, impuso a Yahyà b. 'Umar b. Raḥūu, fiel a su persona, como jefe de los combatientes de la fe (šayj al-guzāt).

En lo que concierne a su política exterior, podemos destacar que su principal pretensión giró en torno a la búsqueda de una relativa estabilidad que le permitiera consolidar el Estado en sus diferentes aspectos. Así, en este

\footnotetext{
I La reproducción fotográfica de las obras de restauración de 1893 corresponde, únicamente, a la reedición de I899 de A. ALMAGRO CÁRDENAS.
} 
contexto se firman importantes tratados de paz y se pactan periodos de tregua, como el que se sella al año siguiente de su ascenso al poder con Castilla y Fez (1334), al que en I 335 Aragón se suma. Esta paz duraría hasta los años 40 en los que se reinician las hostilidades por el control del estrecho, cuyo episodio más destacado y decisivo es el de la célebre batalla del Salado (o Tarifa, según las fuentes árabes), que abriría una etapa de hostilidades hasta 1344. Sin embargo, en marzo de este año se firmaría una nueva tregua para 10 años comprometiéndose el sultán granadino a pagar 12.000 doblones. Se recupera con esto el anterior periodo de estabilidad y paz que resulta fundamental para comprender la política de expansión urbana y constructiva de Yūsuf I. Así en este plazo se erigen entre otros: la madraza (1349), que es nuestro actual objeto de estudio, se construye la Bāb al-Šarìta (mal llamada Puerta de la Justicia, I 348) y la Puerta de Siete Suelos (o Bāb al-Gudūr, de los pozos), el Palacio de Comares, la Torre del Cadí, la Cautiva, los baños reales y la mayor parte de la decoración del Alcázar Genil. Hay que recordar que se inicia la etapa de los grandes visires y secretarios como Ridwān e lbn al-Jațîb entre ellos, siendo el primero clave en la fundación de la escuela de estudios superiores granadina.

Yūsuf I moriría, asesinado en octubre de 1354, al ser apuñalado por un esclavo de las caballerizas en la mezquita mayor mientras realizaba el rezo de 'íd al-Fitr, tras 21 años de sultanato.

\section{El concepto de madraza (مدرسة}

"Madrasa" plural "madāris", es un ism makān ${ }^{3}$ del verbo darasa que significa "estudiar", y en cuya forma verbal fa "ala 4 quiere decir "enseñar Derecho". El "mudarris", que es un ism fä́il ${ }^{5}$, sería el profesor de Derecho. Por lo tanto, el término madraza sería etimológicamente el lugar en donde se estudia Derecho islámico. Según Pedro de Alcalá la madraça era una "universidad de estudio" (PEZZI, 1989: 589). El prestigioso diccionario árabe-francés de Kazimirsky nos precisa que es una "École supérieure, collégue academie" (KAZIMIRSKI, 1860: 688) y en la última versión del DRAE "madraza" es definida como "Escuela musulmana de estudios superiores". Por lo tanto, podríamos concluir que el término madraza, designaría, un centro de enseñanza superior en el que se estudiaba como materia primordial el Derecho y otras ciencias islámicas, así como Lengua, Gramática árabe, Literatura, Filosofía y otros contenidos (CABANELAS RODRÍGUEZ, 1988: 31).

Por otra parte, conviene advertir la incoherencia cultural que supone identificar el concepto de madraza al de Universidad, como si uno fuera el equivalente al otro ya que ambos fenómenos son el fruto de la evolución de la enseñanza en dos formaciones socio-económicas distintas, la tributaria-mercantil y la feudal, y de dos entidades socio-culturales diferentes, la Cristiandad y el Islam. Las dos constituyen el grado superior $y$, en cierta forma, formalizan y estandarizan, más en el caso del segundo que en el del primero, la formación. Sin embargo, tanto en su origen como en su funcionamiento existen diferencias insalvables. Algunas de éstas ya fueron señaladas por el investigador George Makdisi (1970: 255-264), pasamos a resumirlas a continuación.

Cuando hablamos de Universidad en el mundo medieval cristiano nos referimos a una comunidad o corporación en la que se protegen los intereses de maestros y alumnos. En este sentido habría que tener en cuenta el contexto feudal en el que se insertan, en el que los extranjeros pueden sentirse amenazados por los cambios de jurisdicción. En cambio, en

\footnotetext{
2 Pronunciada [madrasa] pero como otros muchos arabismos, como azalá, zuna, zahora..., ha pasado con "z" al castellano, quizás por el ceceo o por mera deformación.

3 Nombre que indica el lugar donde se desarrolla una acción.

4 Forma $2^{a}$ según la clasificación tradicional que los arabistas españoles hicieron en su tiempo.

5 Una especie de participio activo.
} 
el caso de la madraza se trata de un edificio o conjunto constructivo en el que se suelen englobar un oratorio, alcobas para alumnos, bibliotecas e incluso la tumba de su fundador, como sucede en Oriente.

Las madrazas de una misma ciudad eran completamente independientes unas de otras, no existía un organismo que las coordinase, sin embargo éste no es el caso de las universidades. Resulta evidente que, esta diferencia nos refleja dos sociedades si no opuestas, divergentes. En el mundo islámico no tendría sentido la constitución de corporaciones ya que en éste las personas tienen las mismas obligaciones y derechos independientemente de la ciudad en la que se encuentren. No es así, el caso de la Europa feudal en la que en cada ciudad y señorío puede cambiar la jurisdicción.

Otra de las grandes diferencias estaría relacionada con el distinto grado de organización y centralización. No cabe ninguna duda de que en las ciudades europeas, como Paris, la Universidad sólo era una, en cambio en el caso del Islam, las madrazas podrían ser numerosas. Para hacernos una idea en Bagdad había alrededor de 30 en I |84, si damos crédito al testimonio de lbn Ŷubayr (Rihla, I64, Voyages, 262 y trad. MAílLO, 27) y todas ellas eran independientes. Esto hacía que en el mundo feudal la enseñanza fuera mucho más jerárquica y organizada y en el caso del Islam más individual y personalizada.

Pero, como señala Makdisi, tal vez la diferencia fundamental entre Universitas y madraza resida en el sistema de certificación ya que, mientras en el caso cristiano el consentimiento de la autoridad pertinente de la Iglesia era determinante para que el maestro otorgara al alumno la licentia docendi sobre cierta materia, incluso podía anular las licentiae concedidas. En cambio, en lo que se refiere a la madraza, la iŷaza era una cuestión personal entre el maestro y el estudiante en el que nadie podía interve- nir; aquél le concedía a éste el permiso para enseñar una obra suya o que había aprendido de otro profesor, se formaba así una cadena de transmisión que constituía el currículo de los estudiantes (MAKDISI, 1970: 260-264).

Todo esto nos lleva a la conclusión de que tenemos que mantener cierta cautela a la hora de traducir madraza por universidad ya que ambos conceptos responden a realidades que si bien podrían presentar ciertas concomitancias, se hallan muy dispares.

\section{Orígenes de la madraza}

Ya ha sido tratado en otros trabajos in extenso las diferentes hipótesis sobre los orígenes de la madraza, lo cual nos exime en parte de entrar en detalles, por lo tanto, sólo nos cabe indicar aquí algunas ideas generales sobre el surgimiento de estas madāris sin profundizar en las posibles influencias.

El desarrollo de esta institución se da sobre todo en el siglo $X \mid$ en Oriente, y se ha querido ver en Nižām al-Mulk, visir del sultanato selŷuqī en tiempos de Alp Arslān ( I063-1072) y Malik Šāh (1072-1092) que prácticamente ejercía todo el poder político, como el principal promotor de las madrazas estatales ya que es él quien las oficializa y el que hace que se multiplique su número de forma vertiginosa ${ }^{6}$. Un hecho sintomático de lo que venimos apuntando es que en 1067 ordena construir su primera madraza y en el I | 84, como señalamos supra, ya había 30 en la parte oriental de Bagdad.

Sin embargo, en lo que respecta al norte de África, hay que esperar al 1249 para ver la aparición de la primera madraza, nos referimos a la al- Šammāiryya mandada a construir por el sultán hafșí Abū Zakariyyā en 1249. Tras ésta, una década más tarde, la viuda de este personaje financió la construcción de otra denominada

\footnotetext{
6 Aunque no cabe ninguna duda de que las madrazas, como organismos independientes de las mezquitas se remontan más allá de este personaje.
} 
al-Ma'riḍiyya 7 . Poco después se levantará la más antigua que resta en el Magreb, la Madrasat alȘaffärīn, fundada en 1271 por el sultán meriní Abū Yūsuf en Fez, y así proliferarán a lo largo del siglo XIV en todo el Occidente islámico, promovidas sobre todo por los meriníes en una clara política de crear a una élite religiosa oficial: la al-'Aț̣ārīn (I 325), la Bū 'Ināniyya (I350-55) son dos de las más destacadas de este periodo (TERRASSE, 1927). Un caso anterior incluso a los señalados es el de Ceuta, donde un experto en hadiț, fiqh y adab llamado Abū-I-Hasan Muḥammad al-Gāfiqī al-Šarrī funda en '1238 una madraza y posteriormente, previa incluso a la que nos ocupa en este artículo, en 1347 el meriní Abū-l-Hasan manda a construir la Madrasa al-Ŷyadìda (MARTíNEZ ENAMORADO, 1998: 29 y 2002: 39-58).

Conviene señalar que la aparición de estos centros de estudio es el resultado de la evolución del sistema formativo del mundo arabo-islámico. En dicho desarrollo se han discernido tres estadios, dos previos a la madraza. En un primer momento, la enseñanza estaría exclusivamente concentrada en las mezquitas (masāŷid) en las que el imām o maestro de turno impartía clases de Corán, hadit y y otras ciencias. Tras esto, en una segunda fase, a este lugar destinado al azalá se le agregaría otro para el hospedaje de los alumnos: el jān. Éste último sería el precedente más inmediato de las madrazas en las que la finalidad primordial se invierte, la enseñanza se convierte en la función principal, y al mismo tiempo se ofrece alojamiento tanto a los estudiantes extranjeros como a los pobres (PEDERSEN et alii, 1985: || |19-1 |30).

\section{LA MADRASA YÜSUFIYYA}

\section{Su ubicación}

Como nos señala Seco de Lucena (1975: 65-67), el edificio se abría a la plaza de la mezquita mayor (rahbat al-Masŷid al-A'żam) la cual ocupaba el espacio libre entre el palacio de la Madraza y la Capilla Real. Estaba, pues, en una zona que entonces constituía el principal centro social, económico y religioso de la Granada islámica, en lo que sin duda era el corazón de la medina. Esto mismo recordó en su tiempo Henríquez de Jorquera en sus Anales:

"Las casas del cavildo y aiuntamiento desta
ciudad están en lo mejor de ella y en su
mayor comercio. Tiene por frontera la Real
Capilla de los Reyes en una acomodada
placeta, en donde tiene puerta la capilla
... Tiene a las espaldas este cavildo la
gran calle de çacatín y a veinte pasos el
Alcayceria; la casa no es muy grande, mas
es de hermosa fabrica mosayca, con un
famoso patio con estanque de agua, su
poco de jardin, sala de cavildo en alto para
imbierno de muy buena y curiosa pintura;
aqui dicen se juntaban a consejo los mo-
ros y le llamaban Madraça. Otros autores
dicen que serbía de escuelas o colejio para
enseñanza de su Alcorán y puede ser que
sirbiese de lo uno y de lo otro" (HENRÍQUEZ
DE JORQUERA, I987: 76-77).

Por lo tanto, conviene tener en cuenta que la elección del lugar no es algo aleatorio sino que está perfectamente planificado. Así siempre, a menos que la configuración urbanística lo impida, tiende a situarse la madraza junto a la aljama (MARTíNEZ ENAMORADO, 1998: 29). Con esto se busca evidentemente estar dentro de un espacio haram, un lugar sagrado, protegido e inviolable.

Según las referencias que tenemos a nuestra disposición, la antigüedad del poblamiento en este espacio que ocupaba la madrasa Yūsufiyya no se remonta más allá del periodo zirí, en el que se funda Madīnat Garnāța (MALPICA, 2000 y 2007: I 40-14I y SARR, 2007: 165-180). Estamos en posición de afirmar que probablemente esta zona ocupada por el solar de la madraza fuera un área privada, al menos en la primera mitad del siglo XI, perteneciente a la élite política y

7 Existe un precedente en Fez fundada por Yūsuf b. Tāšfīn ( 1096 ), desmantelada posteriormente por los almohades. 
social zirí (MALPICA, 2007 y MATTEl, 2008: 191). Así, en esta etapa, como nos señala el último sultán zirí, 'Abd Allāh b. Buluqqīn, habría una almunia vinculada a Habūs y que sería heredada por su sucesor Bādīs:

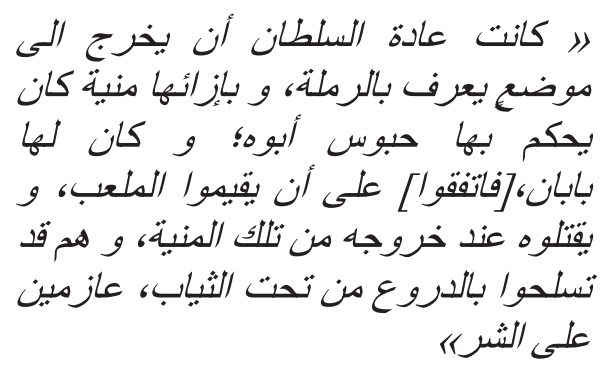

(Al-Tibyān. 1995, 69, líneas 105-106).

"Tenía el sultán por costumbre salir a un lugar conocido por Al-Ramla (el Arenal), a cuyo lado había una almunia en la cual Habūs solía tener su consejo de gobierno ${ }^{8}$, que tenía dos puertas, y (los conjurados) se pusieron de acuerdo en organizar una carrera de caballos y asesinarlo a su salida de esa almunia, ellos se equiparon con una armaduralcota de mallas bajo sus ropajes, estando decididos a cometer el mal". (Memorias, 2005: I20)

Los restos del siglo $\mathrm{XI}$ hallados en la última excavación arqueológica y el seguimiento arqueológico vinculado a ésta ${ }^{9}$ en la madraza yūsufiyya pueden corroborar de manera potencial la hipótesis formulada y la citada referencia escrita. El descubrimiento de un complejo de una envergadura considerable formado por cuatro potentes muros de calicanto, paralelos entre ellos, nos hace suponer que estamos frente a un conjunto relacionado con el poder estatal.

También hay fundamentos para pensar que este conjunto haya sido de uso residencial y que al mismo tiempo haya tenido un destino de uso agrícola, al menos hasta la construcción de la mezquita aljama, encajando perfectamente con dos de las características que son propias de una almunia y reforzando la perspectiva de nuestra suposición.

El primer testimonio, es la naturaleza de uno de los tres muros de calicanto, con más precisión el que se quedaba en el interior del recinto, que coincide con la parte occidental del solar. Se trata de un muro contraterrero, cuya función primaria era aislar de la humedad, demostrando la intención de sanear la zona interior, y por lo tanto, nos indica que puede pertenecer a un lugar doméstico. De esta manera se evacuaban las aguas formadas por la humedad a través del espacio presente entre este muro y el que tenía como destino la delimitación perimetral del recinto del área, que era el muro de mayores dimensiones (Lám. 3).

La cerámica hallada en los niveles asociados a estas estructuras, también fortalece la idea de que se pueda tratar de una almunia perteneciente a la élite del momento. Sus características indicaban una factura de muy buena calidad y un destino de uso de tipo doméstico.

En el texto mencionado supra de las Memorias de 'Abd Allāh, se hace referencia a dos puertas, que creemos oportuno entender como dos entradas distintas al recinto. Sin embargo, en la excavación se encontraron los vestigios de dos puertas una al lado de la otra, o mejor dicho, un único acceso de tipo monumental, que podría en la mejor de las hipótesis ser uno de los citados más arriba. Efectivamente en la parte exterior al supuesto muro perimetral, había otro paralelo y a una distancia de 2,5 m aproximadamente. El muro, conservado sólo en su parte inferior, estaba interrumpido por dos vanos que configuraban las dos puertas. Esto lo podemos afirmar por la presencia de

8 De hukm, nombre del consejo.

9 Dicho seguimiento arqueológico ha sido consecuencia de la obra de rehabilitación del edificio posterior a la excavación del 2006. Éste ha sido llevado a cabo por Antonio Malpica Cuello y Ángel González Escudero a los que agradecemos habernos proporcionado los datos más recientes de éste para incluirlos en este trabajo. 
sillares de arenisca que constituían sus jambas y por una quicialera hallada en el umbral de una de ellas (Lám. 4) ${ }^{10}$. La presencia de este muro con sus dos puertas en la parte exterior organizaba un pasillo de tránsito entre éste y el potente muro perimetral, comunicando el exterior con el interior y permitiendo el paso a personas.

Una última evidencia que puede respaldar todo lo dicho, constituye la acequia que corre fuera del recinto residencial y que en su proximidad quiebra para después seguir paralelo a él. En una almunia, como es bien sabido, es fundamental aportar agua para las labores agrícolas, y por esta razón casa perfectamente la presencia de este ramal, que está construido en su parte inferior con cajones de tapial hormigonado, típico de las estructura hidráulicas. Próximo al mencionado ramal, estamos en posición de afirmar que estaría la zona destinada a los espacios de producción, gracias a la exhumación de una prensa y al hallazgo de un ulterior muro de tapial de calicanto caracterizado por la presencia de otros dos vanos cuyas jambas estaban realizadas con piedras de calcarenitas similares a las anteriores (Lám. 5). Este muro pertenece junto a otros restos de menor entidad al cuerpo de fábrica donde se desarrollaban actividades productivas.

Por otra parte, sobre el contexto en el que se ubicaba la madraza contamos con la visión que de la zona nos ofrece al-'Umarī en el siglo XIV, en tiempos de Yūsuf I, poco antes de la fundación de este señero edificio, 738 $\mathrm{H} / \mathrm{I337}$ :

"Le grande mosquée de Grenade est un édifice puissant et magnifique, auquel n'est accolé aucun autre bâtiment; elle est seulement entourée des échoppes des témoins assermentés et des boutiques des droguistes". (Masāilik, 1927: 233).
Probablemente cercano al lugar adonde se erige este edificio o en el mismo solar, según la opinión de Almagro Cárdenas, se levantara la llamada casa marmórea de Muhammad b. Sa'îd b. Jalaf Abū Bakr Ibn Yāsir, gobernador almorávide de Granada.

"Mohamed Ibn Said Ibn Jalaf, natural de Alcalá la Real, obtuvo de los reyes almorávides el gobierno de Granada y adornó la ciudad con edificios, como la casa marmórea que construyó para sí junto a la aljama para su habitación, que luego sería convertida en Madraza por Yusuf I" (ALMAGRO CÁRDENAS, 1877) ${ }^{\prime \prime}$.

Esto nos lo recuerda mencionando el texto del arabista y bibliotecario Miguel Casiri en su Bibliotheca Arabico-Hispanae Escurialensis:

"Mohamad Ben SAID DEN KHALAF ABA BAKERUS BEN IASER ex oppido Calat lahseb (قلعة بحصب), nunc Alcala la Real, ubi ortus est anno Egirae 483. Hic Regibus Almoravitis, Granatae Pareturam obtinuit, opibus et auctoritate plurimùm valuit; urben amplis et illustribus aedificis ornavit: in quibis domus illa Marmorea ( ) celebratur, quam juxta Granatae templum maximum sibi suisque sumptiosiùs extreundam curavit. Ibi vitae finem implevit anno Egirae 539. Complura ejus, tùm aliorum in ejusdem laudes carmina Codex Scriptor ALGAPHEKAUS in Hispaniae Annalibus" (CASIRI, 1770: 92 c. I.).

La cita de al-'Umarī y la consideración de Almagro, también tienen una argumentación justificada a nivel arqueológico. De hecho, los vestigios exhumados pertenecientes a la época almohade y a la época nazarí antes de la construcción de la Madraza, ponen de manifiesto cómo el edificio se construye en

\footnotetext{
I0 Cabría destacar la gran similitud entre esta jamba y las aparecidas en la excavación realizada en el interior del torreón SE de la alcazaba de Guadix que también se han datado en el siglo XI. (SARR et alii, 2006: I27-|44).

I I En realidad desconocemos de dónde procede el dato exacto que indica que esta casa marmórea estuviese en ese mismo solar, ya que la fuente a la que remite no especifica nada de eso como se puede observar en el texto expuesto a continuación.
} 
el lugar donde existía una manzana ocupada por viviendas que se encontraban arrasadas y cortadas por los cimientos de los muros de mampostería encintada de la Madraza. Como si no fuera bastante, se ha constatado también una densificación de los espacios construidos, consecuencia de un considerable crecimiento demográfico ocurrido en el siglo XIII y en la primera mitad del siglo XIV.

En lo que se refiere a la época castellana, conviene señalar que desde el 1500 se convierte en el cabildo o Ayuntamiento de Granada en virtud de una concesión que realizan los Reyes Católicos. Así en la cédula publicada a la cabeza de las Ordenanzas de Granada se expresa:" "Item damos para casa de Cabildo la que los moros Ilaman Almadraza" (ALMAGRO CÁRDENAS, 1877:201). En estos primeros momentos, se acometería también una ampliación del edificio con la anexión de una casa colindante (CRUZ et alii, 2007: 56 y GALERA MENDOZA, 2000: 9-21). Posteriormente sufrirá más alteraciones, pero éstas y el acontecer de la madraza en época moderna escapan ya a los contenidos del presente artículo.

\section{Su fundación}

Como ya indicamos, la erección de un edificio tan insigne como fue la primera madraza pública de al-Andalus debe insertarse en el contexto del magno programa constructivo y monumental de Yūsuf I en el que se incluyen otras obras de gran entidad, como la reforma de la alcaicería, algunas de las construcciones más destacadas en la ciudad palatina de la Alhambra y la del puente y alhóndiga nueva llevadas a cabo todas en una etapa de estabilidad y de relativa paz tras la firma de treguas como explicamos anteriormente.

Sería conveniente señalar que en estas obras tendría un papel decisivo el hāâyib Riḍwān que, emulando al gran visir selỳuqī, fue quien ordenó la construcción de la madraza granadina (SECO DE LUCENA PAREDES, 1956: 285-296), como bien nos precisa Ibn al-Jațīb en su Ihăța:

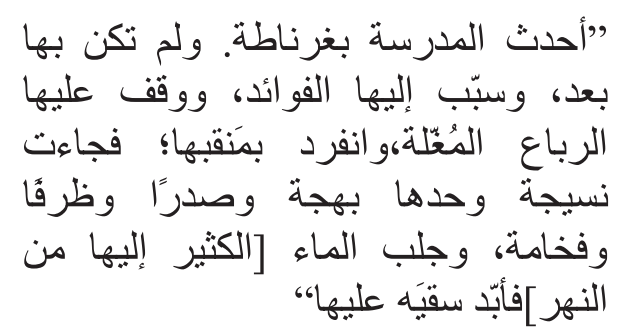

(Ihāța I, 508-509).

"Fundó la madraza de Granada, donde aún no existía, le asignó rentas, estableció en ella celdas provechosas [para los estudiantes] y nadie le aventajó en favorecerla; llegó a ser única por su esplendor, encanto, elegancia y grandeza y llevó a ella agua abundante del río haciendo que su riego sobre ella fuese permanente" (CABANELAS 1988:30).

Este personaje, cuyo nombre completo es Abū-l-Nu'aym Riḍwān ibn 'Abd Allāh alNașrī, fue suficientemente analizado por el arabista Seco de Lucena en un artículo en el que comenta la biografía que incluye Ibn al-Jațîb en su I hạța (SECO DE LUCENA PAREDES, 1956:285-296; IHĀTTA I: 506-5I3), por lo que quedamos dispensados en cierta forma de entrar en pormenores. Sólo destacaremos que se trataba de un visir de origen cristiano, nacido en la Calzada de Calatrava, que fue capturado en una de las expediciones del reino nazarí. Éste sería educado en el Islam para realizar las tareas propias de un esclavo palatino. Pronto destacará por sus habilidades, así Ismāîl I lo puso a su servicio antes de ser sultán hacia el 1314 y se dedicaría a la educación de su propio hijo, Muhammad IV quien le nombraría después hāâyib y nāilb. Así comienza una carrera política que le convertirá en una de las personalidades más importante del siglo XIV y de la historia del reino nașrí. Posteriormente ocupará los mismos cargos con Yūsuf I, de quien fue regente en sus primeros años debido a su minoría de edad, y con Muhammad V. Morirá asesinado el 23 de agosto de 1359/ 28 de ramaḍān 760, acuchillado por unos sicarios mandados por el rebelde Abū Sa'îd, futuro Muhammad VI el Bermejo. 
Debe destacarse que este Riḍwān, como apuntábamos antes, fue el promotor de importantes obras de carácter público. Así él mismo se encargó de que se dotara de agua al barrio de Mawrūr, ordenó levantar la imponente cerca del arrabal del Albayzín y además se preocupó de reforzar las fronteras mandando levantar una cuarentena de torres atalayas que controlasen el acceso al reino por el occidente, desde Vera a los alfoces occidentales (Ihätă I, 509).

Conviene que nos detengamos en dos hechos que nos pueden interesar dentro de su biografía y que influyeron de forma decisiva en la gestación de la idea de construir una madraza en la capital granadina. Nos referimos a las dos estancias que Riḍwān realizó al otro lado del mar: primero, exiliado en Tremecén (desde una fecha posterior a junio 1328 /raŷab 728) (Ihāața I, 5 I 0 y SECO DE LUCENA, 1956:288), cuando Ibn al-Mahrūq le conmuta su pena de cárcel por su destierro, allí estaría unos meses hasta que Muhammad IV recupera el poder y le pide que vuelva, (hecho que se daría hacia el 6 noviembre del $1328 / 2$ de muharram 729),y luego, el 17 de septiembre de $1332 / 24$ de dūI-hiŷŷa 732, marchó a Fez junto a Muhammad IV para gestionar una alianza con los meriníes, entonces dirigidos por Abū-I-Hasan 'Alī, frente a los castellanos (Ihäța I, 536 y SECO DE LUCENA, 1956: 289).Y es que este tiempo que pasó en el norte de África probablemente le posibilitaría conocer de cerca el funcionamiento de las madrazas allí sitas, y por ello resulta verosímil que trajera consigo una idea que desarrollaría a finales de la década de los 30.

Por cierto, volviendo al texto anterior de la Ihāța, referido a la fundación de la madraza, deberíamos matizar que el comentario "donde aún no existía" se refiere a la ciudad de Granada ya que, como conocía el mismo lbn al-Jațīb y nos apuntó en su tiempo la profesora Rubiera Mata (1970, 223-226), existió otra madraza en Málaga anterior a ésta en la segunda mitad de la década de los 30 del siglo XIV, es decir, entre I 335- I 340, fundada por el sufí Abū 'Abd Allāh al-Sāhilī . En cambio, ésta difiere de la Yūsufiyya en que fue de carácter particular y no estatal. $Y$ además no fue una madraza ortodoxa sino sufí perteneciente a una secta mística ${ }^{12}$. Por lo que podríamos señalar que la Madraza Nașriyya, como también se le conoce, no fue la primera en al-Andalus aunque sí la primera promovida desde el punto de vista estatal y ortodoxa y la única de la que hasta ahora poseemos restos.

De hecho, en otra de las referencias sobre la madraza, en este caso en al-Lamha al-badriyya, el polígrafo lojeño puntualiza que es la primera de las madrazas «en su capital»:

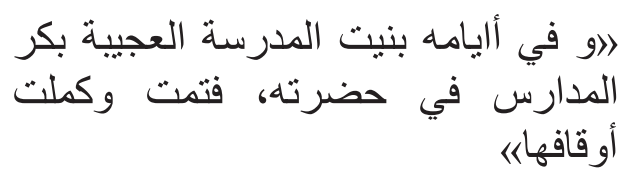

"En su tiempo [Yūsuf I] fue construida la admirable madraza (madrasa) - la Virgen de las Escuelas (bakrat al-madāris)- en su capital; fueron completados y cumplidos sus legados píos (awqāe)". (Lamha, I09/ Reyes, 120) ${ }^{13}$.

Precisamente este texto nos plantea otra cuestión, como es el mantenimiento económico de la madraza. Ésta, como se nos indica aquí, gozaba de una serie de rentas procedentes de los bienes habices (waqf) que se les otorga en el momento de su fundación. Éstos incluyen tierras, tiendas y otros inmuebles productivos, cuyas rentas estarían destinadas a la madraza, y un suministro permanente de agua. Además a todo esto se les iría agregando otras dona-

\footnotetext{
12 Conocemos esta madrasa al-Sāhilī merced a uno de los poemas incluidos en el dīwān que lbn al-Jatīb recopiló de su maestro lbn alŶayyāb en el que se nos señala que fue escrito «para felicitar al šayj,jațīb y sufí Abū 'Abd Allāh al-Sāhilī por haber construido la madraza de Málaga, primera obra de este tipo que se realizó en al-Andalus. Esta madraza, al parecer, estaba situada al occidente de la mezquita mayor y había sido dotada de un waqf. (RUBIERA MATA 1970: 226 y 1994: 177).
}

13 Aunque preferiríamos traducir como primogénita o primera en vez de "virgen" que carece de sentido en este contexto. Asimismo debemos aclarar que en la edición que utilizamos no aparece por error la tā' marbūța característica del femenino en el adjetivo bakr. 
ciones realizadas con posterioridad a su fundación (CABANELAS, 1988:36-37). Recientemente Antonio Malpica ha puesto de manifiesto, a raíz de la última intervención de apoyo a la restauración de la muralla de la Alberzana, que la expansión de espacios agrícolas que se daría con la construcción del albercón allí ubicado tenía como objeto financiar el mantenimiento de la madraza (MALPICA, 2007:I52-153).

Otras de las informaciones que poseemos sobre la edificación de ésta nos la proporciona su inscripción fundacional que reza de la siguiente forma:

\begin{abstract}
"Mandó construir esta casa de la ciencia (que Dios la convierta en mansión de equidad y de luz y la haga perdurar a lo largo del tiempo para las ciencias de la religión!) el emir de los musulmanes (protéjalo Dios con su ayuda!), el elevado, el célebre, el noble, el afortunado, el puro, el alto, el magnánimo, el sultán asistido por Dios, Abū l-Haŷŷẫy Yüsuf, hijo del elevado, el noble, el grande, el excelso, el justo, el santificado y muy acepto, el emir de los musulmanes y defensor de la religión, Abū I-Walìd Ismäàl b. Farâ̂ b. Nașr (que Dios le recompense por el Islam sus virtuosas acciones y sus elevados hechos de guerra santa!). Se terminó en el mes de muharram del año 750 [22 de marzo-20 abril 1349 ]" (CABANELAS, 1988: 48).
\end{abstract}

Precisamente gracias a ésta conocemos la fecha exacta del fin de las obras: la primavera de 1349. Tras casi una década desde que se ordenó su construcción hacia el 1340.

\section{Su configuración}

La configuración de la Madraza Yūsufiyya, conocida hasta entonces sólo a través de unas pocas fuentes escritas, ha ido tomando cuerpo a lo largo de su profundizado estudio arqueológico, cuyos resultados iremos exponiendo a continuación.

Según Darío Cabanelas, basándose en descripciones del siglo XVI, la puerta de entrada era un arco de herradura con una inscripción coránica, dintel decorado con una leyenda similar y encima dos losas de mármol blanco primorosamente labrado, imitando dos ventanas, cada una con pasajes de dichas inscripciones (CABANELAS, 1977: 10). Sin embargo, en la interpretación gráfica de Rafael Contreras de fines del siglo XIX difiere la posición de las losas mencionadas, al no conocer las fuentes del siglo $\mathrm{XVI}$ que luego pudo utilizar el primero.

Lo que podemos confirmar a través de la reciente intervención arqueológica es que ésta no se ubicaba donde se encuentra en la actualidad, debido a un potente muro de mampostería encintada que se sitúa justo en la mitad de la entrada actual, y que configura dos espacios distintos a ambos lados.

Uno de estos espacios era con certeza el zaguán, al cual se accedía al pasar la puerta de entrada. Tras éste se pasaba al patio a través de una puerta que no estaba enfrentada a la primera, manteniendo así una cierta intimidad. El patio, que a grandes líneas coincidía con la superficie que ocupa el actual, conservaba en el centro los restos exhumados de la pequeña alberca citada en las fuentes (HENRÍQUEZ DE JORQUERA, 1987: 76-77). Ésta tenía un suelo de ladrillo realizado en espiga, paredes realizadas en ladrillo cuyo paramento era recubierto por una capa de cal, una entrada de agua en su lado septentrional y un rebosadero en su lado occidental. Rodeando la totalidad de la alberca había un andén, que presentaba un pequeño escalón cuya función era meramente decorativa (Lám. 6).

Enterrado y sirviendo de recinto a todo el conjunto de la alberca, se hallaba una estructura de mampostería encintada con su cimentación que, además de servir como contención y dar solidez a la estructura de la alberca, era con toda probabilidad el apoyo donde descansaban las columnas y/o pilares que iban configurando los pórticos del edificio.

Desde el patio, opuesto a su entrada, se accedía al oratorio. La intervención arqueológica ha podido constatar un dato que aún no estaba comprobado. Los cuatros muros perimetrales son con seguridad pertenecientes a la edificación de la Madraza y están construidos en 
mampostería encintada con excelente factura. El análisis mural del oratorio, realizado a lo largo del estudio arqueológico, ha añadido también dos informaciones relevantes. La primera es la confirmación de la ubicación del miḥrāb, que debía ser más profundo pero sin cambiar su ubicación. En segundo lugar, la puerta de entrada al oratorio comunicante con el patio, era de mayor anchura que la actual, visto que se han documentado los pilares que soportaban sus jambas. Es probable incluso que esta entrada presentara en su exterior un estrecho porche, supuesto por la exhumación de la base de un pilar en su proximidad.

Aunque el conjunto patio y oratorio era perfectamente simétrico, la Madraza poseía una planimetría asimétrica. Efectivamente, el lado occidental del patio estaba delimitado por un potente muro de mampostería encintada ${ }^{14}$ lindando con propiedades privadas, mientras que al lado oriental consideramos, siguiendo los datos de las fuentes modernas, que se extendía una crujía a la cual se accedía a través del patio. Ésta debía ser el aula de enseñanza, mientras que en su correspondiente sala superior, a la cual se accedía a través de una estrecha escalera que comunicaba con el patio en su esquina sureste, se podían encontrar las habitaciones de los alumnos separadas por tabiques. Conocemos exactamente la existencia de tal escalera gracias a la descripción que realiza de la puerta de la misma A. Almagro Cárdenas (1877:216-217) y a la transcripción de un documento realizada por Gómez-Moreno González (CRUZ et alii, 2007: 66).

También gracias a los trabajos arqueológicos se ha confirmado la presencia de un pequeño jardín citado en las fuentes (HENRÍQUEZ DE JORQUERA, 1987: 76-77). Éste se hallaba al costado oriental del oratorio y los muros de mampostería encintada que lo delimitaban, nos hacen pensar que estaba bordeado por dos pequeños pabellones.
Un último lugar obligatorio en un edificio de estas características, eran las letrinas. Pensamos que éstas debían situarse en la habitación que flanqueaba el zaguán, lindando con su fachada. Este espacio probablemente debía de incorporar también una pequeña fuente, necesaria para el ritual de las abluciones antes de la función de rezo. Sin embargo, hasta el momento ni las letrinas ni la fuente han podido ser constatadas arqueológicamente al quedar esta zona fuera del área excavada.

\section{Objetivos de su construcción}

Otra de las cuestiones que nos deben suscitar una pausada reflexión es la de los objetivos que pudo perseguir la construcción de la Madraza Yūsufiyya. Con respecto a esto, analizando el contexto histórico en el que se inserta y extrapolando en la medida de lo posible datos de otros casos previos al que nos ocupa, hemos de afirmar que probablemente su fundación tuviera una serie de fines evidentes y otros subyacentes que precisamente acaban representando las verdaderas intenciones. No cabe duda de que entre los motivos a los que se apela están los de la difusión de la ciencia y facilitar la formación de los musulmanes en las principales materias de conocimiento y el de convertir Granada en un centro intelectual de referencia de su tiempo. Sin embargo, no es menos cierto que uno de los fines que subyacen es el adoctrinamiento de los imames, alfaquíes y sabios formados en ella. De esta forma se combate por una parte la heterodoxia sufí, que gozaba de gran extensión entonces, como lo demuestra fehacientemente la fundación de la madraza de Málaga o la proliferación de zawāyya (pl. de zāwiyya), y, por otra, se pretende suprimir todo tipo de cuestionamiento del poder y del orden establecido (SCHAZTMILLER

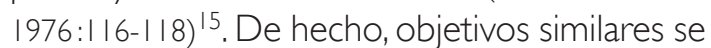
observaron en su momento en la creación de las primeras madrazas del Islām, con el mencionado visir de Malik Šah, Nizām al-Mulk. Es

\footnotetext{
14 Consideraciones derivadas gracias al informe redactado por el equipo del arquitecto D. Pedro Salmerón Escobar y referido a la intervención relativa a los nuevos enlucidos del patio. Inédito.

I5 En el caso de la madrasat al-Șaffarīn se crea para contrarrestar un movimiento de ulemas díscolos.
} 
decir, lo que se pretende es formar un cuadro de funcionarios sumisos a la ideología oficial al mismo tiempo que se utiliza de propaganda religiosa ${ }^{16}$. Por otro lado, como señaló la profesora R. Arié debemos destacar "el deseo de aumentar el prestigio del soberano", y es que la madraza de Granada no se comprende sino dentro de esa magna política edilicia que se desarrolla en tiempos de Yūsuf I y que produce la transformación del reino, especialmente de su capital. Todo ello dentro del lenguaje de legitimación y con la pretensión de aumentar el prestigio de la autoridad en un momento de tregua.

Por su parte, la madraza venía a establecer la regularización de la formación, su estandarización pero a su vez la supervisión de la misma por parte del Estado, lo que permitía encauzar por sus vías la formación de la élite religiosa y cultural y despejar las posibles heterodoxias y formación en ideologías díscolas al poder. No hay que olvidar que la formación en el mundo islámico era en cierta forma "descontrolada": unos alumnos oían durūs (pl. de dars lecciones) de diferentes maestros y pasaban con ellos varios años para obtener lo que se conocía como iŷāza (permiso o licencia por parte del maestro para poderse dedicar a enseñar por su cuenta). Por lo que, en cierto sentido, se puede señalar que el poder central no actuaba directamente ni ejercía un control total sobre todos los procesos formativos.

Otro factor a tener en cuenta es la influencia meriní que vemos incluso materializada en los aspectos constructivos de la misma ${ }^{17}$. Los contactos entre ambas entidades fueron constantes durante su existencia y los benimerines habían construido una madraza durante el siglo anterior. Íntimamente vinculado a esto, cabe aquí señalar la probable mímesis por prestigio como señala el profesor Virgilio Martínez Enamorado (2002: 28).

\section{Profesores, alumnos y materias impartidas}

Sabemos de las materias impartidas en la escuela islámica granadina merced a las especialidades de cada profesor y extrapolando datos de otras madrazas. Así podríamos señalar que la materia central, como en la mayoría de las madāris, era el estudio del Corán y de los comentarios de este libro sagrado (tafsir), los hadices y el fiah. No obstante, había otros contenidos secundarios o auxiliares como el estudio de la lengua árabe, al-nahw (Gramática) y Literatura. También existe constancia de que se enseñaron otras materias como Medicina, Geometría, Lógica, Mecánica y Astronomía.

Sobre sus profesores nos informa lbn alJațīb en su Ihāta y nos habló el arabista Darío Cabanelas en un artículo dedicado a la madraza (CABANELAS, 1988: 37-39). En ésta, según el lojeño, estuvieron reputados maestros lo que la convierten en un centro cultural de referencia de todo el Islam. Destacamos personajes como Abū 'Abd Allāh Muhammad b. Muhammad b. Muhārib al-Ṣarīhī al-Mālaqī alias Ibn al-Ŷyay̌̌ (Ihạta III, 78-79, Nayl, 249) (m. I 349), Abū 'Abd Allāh b. Ibrāhīm b. Muḥammad al-Sayyārī al-Bayyānī (m. I 352) especializado en jurisprudencia, lengua árabe, derecho de sucesiones (Dibāŷy II, 276-277, al-Durār III 382, n 3308), Abū Zakariyā Yaḥyà b. Ahmad b. Hudayl al-Tuŷibī, que fue maestro de lbn al-Jațib y era experto en principios del derecho, derecho de sucesiones y medicina) (Ihāța IV, 390-40I). Otro era Abū 'Abd Allāh Muhammad b. 'Alī b. Aḥmad al-Jawlānī conocido como lbn al-Fajjār y al-Ilbīīi (experto en Gramática árabe, jurisprudencia, métrica y tafsir (Ihāța III, 35-38, Nafh V, 383), Abū Muhammad b. 'Abd Allāh b. Abī-l-Qāsim b- Ýuzayy al-Kalbī (lengua árabe y modismos) (Ihātạa III, 392-399, al-Kātiba, 96 y 99 , Hadiyyat, 160) Abū 'Alī Manșūr b. 'Alī b. 'Abd Allāh al-Zawāwī (ramas del derecho y el tafsirr) (Ihătata III, 324-325 y 330 y Nayl, 345-346), Abū Sa'îd Faraŷ

\footnotetext{
16 "Former une élite de propagandistes convaincus de fonctionnaires fidèles, d'agents sans cesse en contact avec le peuple, telle était la mission de la madrasa" (GOLVIN, I $995: 20)$.

17 Como bien señala el arabista Francisco Vidal existe una historia compartida de al-Andalus con el Magreb en los siglos XI-XIII y paralela desde la $2^{a}$ mitad del s. XIII al XV (1995: 17) y se puede seguir en una amplia bibliografía.
} 
b. Qāsim b. Aḥmad b. Lubb al-Ṭa'labī (Ihāța IV, 253-254, Nafh V, 5II, Nayl, 219, Natiri, 186-196), Abū 'Abd Allāh Muḥammad b. Aḥmad b. Muḥammad b. Abī Bakr b. Marzūq al-'Aȳìsī enseña desde el I 352 lecturas coránicas y mística Ibn Zamrak fue alumno suyo (Ihāta III, I03-105, Nayl, 267-269, Nafh V, 4I2-4|3.). Y ya del siglo XV Ibrāhīm b. Muḥammad b. Fatūḥ al-'Uqaylī (Ibn Fatūḥ) que fue un destacado muftí (Nayl, 53-54.).

\section{CONSIDERACIONES FINALES}

A modo de conclusión podemos señalar que la Madraza nașriyya nace en el periodo de mayor esplendor cultural del reino nazarí y que se trata de una obra piadosa tendente a aumentar la legitimidad político-religiosa del sultán granadino no sólo por la propaganda que supone una construcción de carácter público y religioso, sino también por su finalidad última de estandarizar la enseñanza y controlarla, formándose así unos dóciles cuadros de élite religiosa.

La última intervención, del 2006, nos ha ofrecido la posibilidad de obtener una planimetría, en parte, muy fiable de este edificio emblemático, hecho de gran valor, al ser el único ejemplar que ha sobrevivido en alAndalus (Fig. 2). Sus dimensiones, y sobre todo su configuración, formado por un zaguán, un patio con pequeña alberca, un oratorio, una crujía lateral que albergaba aulas destinadas a la enseñanza, un pequeño jardín y un acceso a la segunda planta a través de estrechas escaleras; nos recuerdan a las madrazas que se encuentran en el mundo meriní, especialmente la al-'Ubbād de Tremecén (Lám. 7), la de al-'Atțārīn de Fez (Lám. 8) y la Bin Yūsuf de Marrakech. Estas similitudes se explican en un contexto de influencias constantes entre las dos orillas y parece ser fruto y consecuencia directa de las experiencias y conocimientos que le aportó al hāŷib Riḍwān su estancia en el norte de África, que coincidió con el período fundacional de estos edificios. Por ende, Riḍwān, como ya señalara Seco de Lucena, ha de considerarse como el verdadero impulsor y artífice de la Madraza, promovida por Yūsuf I dentro del programa constructivo ejecutado en las proximidades de la mezquita mayor.

\section{FUENTES}

AL BAGDĀDĩ: Hadiyyat al- 'Ārifīn II, Beirut, 1955.

IBN AL-AHMAR: Națir al-ŷumān, Beirut, 1976

IBN BULUQQİN, 'A.: Kitāb al-Tibyān li-l-amīr 'Abd Allāh b. Buluqqīn, ajir umarā' Banī Zïrí bi-Garnāta ed. introd. y notas por A. Tawfiq al-Tīibi. Al-Ribat: Mansurat 'Ukaz, I995/ El siglo XI en primera persona. Las "Memorias" de 'Abd Allāh, último rey Zirí de Granada, destronado por los almorávides ( I 090), trad. E. Lévi Provençal y E. García Gómez, Madrid, $7^{\mathrm{a}}$ ed., 2005.

IBN HAŶAR: al-Durār al-Kāmina III, El Cairo 1966.

IBN AL-JATTīB: al-Kātiba al-Kāmina ed. Beirut, 1963.

IBN AL-JAṬ̄īB: Al-Ihāța fĩ ajbār Garnāța I, ed. 'A.'Inān, El Cairo, 1973 (=lhạța).

IBN AL-JAṬīB: Al-Lamha al-badriyya fĩ I-dawla I-nașriyya, Beirut: Dār al-Āfāq al-ŷadīda, 1980 (=Lamha) y de la trad. titulada Historia de los Reyes de la Alhambra: El resplandor de la luna llena (Al-Lamha al-badriyya), traducción e introducción de J. M. CASCIARO RAMÍREZ, y estudio preliminar por E .MOLINA LÓPEZ, Granada, 1998 (=Reyes)

IBN ŶUAYR: Riḥla, ed. M.M. Ziyāda, Beirut, 1968. Riḥla Voyages, trad. al francés y notas. Guadeffroy-Demombynes, $2^{a}$ parte, París, 1949-53. IBN ŶUBAYR, Riḥla. A través de Oriente. EI siglo XII ante los ojos. Introd., trad. al castellano y notas F. Maillo Salgado, Barcelona, 1988.

AL-MAQQART̄: Nafḥ al-Ṭibb V ed. I. 'Abbās, Beirut, 1968.

AL-TUNBUKTT̄, A.B.: Nayl al-ibtihāây, ed. marginal al-Dibāŷy de Ibn Farḥun, Beirut, s.d., (=Nayl).

AL-'UMARĪ, Ibn Faḍl Allāh: Masālik al-Abșār fĩ mamālik al-amșār I, L'Afrique,moins I'Égypte, Trad. y notas por M. Gaudefroy-Demombynes, París, 1927.

\section{BIBLIOGRAFÍA}

ACIÉN ALMANSA, M. (1995): "Inscripción de la portada de la Madraza", en VV.AA.: Arte islámico en Granada. Propuesta para un Museo de la Alhambra. Granada, pp. 337-339.

ALMAGRO CÁRDENAS, A. ( 1877): Inscripciones árabes de Granada y apuntes arqueológicos sobre la Madraza, Granada.

ALMAGRO CÁRDENAS, A. ( 1899 ): Museo granadino de antigüedades árabes, Granada.

ARIÉ, R., (1990 y 1992) L'Espagne musulmane au temps des Nasrides (I 232-I 492), París, 1990 traducción al castellano El reino nașí de Granada (1232-1492), Madrid, 1992. 
BERNABÉ PONS, L.F. (2007): “El sistema educativo en alAndalus: las madrazas", en LÓPEZ GUZMÁN, R. y DÍEZ JORGE, Ma. E. (ed.), La madraza: Pasado, Presente y Futuro, Granada, pp. I I-24.

CABANELAS RODRÍGUEZ, D. (1977): "Inscripción poética de la antigua madraza granadina", Miscelánea de Estudios Árabes y Hebraicos. XXVI, pp. 7-26.

CABANELAS RODRÍGUEZ, D. (1988):"La Madraza árabe de Granada y su suerte en época cristiana", Cuadernos de la. Alhambra. vol. 27, pp. 29-54.

CASIRI, M. (I770): Bibliotheca Arabico-Hispanae Escurialensis, Tomo II (Tomus Posterior), Madrid.

CONTRERAS Y MUÑOZ, R., (2007): Estudio descriptivo de los monumentos árabes de Granada, Sevilla y Córdoba ó sea La Alhambra, el Alcázar y la Gran Mezquita de Occidente, (Edición facsímil de la de 1885) Mairena del Aljarafe.

CRUZ CABRERA, J.P. y GÓMEZ-MORENO CALERA, J.M. (2007): "Estudio histórico-artístico del Palacio de la Madraza, antigua Casa del Cabildo de Granada", en R. LÓPEZ GUZMÁN Y Ma. E. DÍEZ JORGE (eds.), La Madraza: pasado, presente y futuro, Granada.

GALERA MENDOZA, E. (2000): "Noticias sobre algunas de las primeras reformas urbanas de la ciudad de Granada tras la conquista (1492-1513)", Cuadernos de arte de la Universidad de Granada, 31, pp. 9-21.

GARCÍA-ARENAL, M. y VIGUERA, Mª. J. (1988): Actas de coloquio "Relaciones de la Península Ibérica y el Magreb (ss. XIII-XVI)", Madrid.

GARCÍA BUENO, A., HERNÁNDEZ PABLOS, A., MEDINA FLÓREZ,V. J. (2007): "Estudio previo a la restauración de las yeserías del Oratorio de la Madraza (metodología y avance de resultados", en R. LÓPEZ GUZMÁNY M ${ }^{a}$. E. DÍEZ JORGE (eds.), La Madraza: pasado, presente y futuro, Granada, pp. 277-304.

GOLVIN, L. (1986): "Quelques réflexions sur la fondation d'une madrasa à Grenade en 750=|349", Actas del X|| Congreso de la U.E.A.I. (Málaga 1984), pp. 305-313.

GOLVIN, L. (1995) : La Madrasa médiévale: architecture musulmane, Aix-en-Provence.

GÓMEZ-MORENO GONZÁLEZ, M. (1982), Guía de Granada, Granada, 1892. Edición facsímil Universidad de Granada, Granada.

GONZÁLBES BUSTO, G. (1975):"'La enseñanza de España musulmana", Cuadernos de la Biblioteca española de Tetuán. I I (1975), pp. 7-35.

GRANDIN, N. y GABORIEAU, M.(1997) : Madrasa: La transmission du savoir dans le monde musulman, París.

HENRÍQUEZ DE JONQUERA, F. (1987): Anales de Granada, Edición del impreso original de 1646, Granada, pp. 76-77.

KAZIMIRSKI, B. ( I 860) : Dictionnaire arabe-français. Tomo I, Beirut.

LADERO QUESADA, M. A. (1989), Granada. Historia de un país islámico (| 232-157|), Madrid, $3^{\mathrm{a}}$ ed.
MAKDISI, G. (|96|): "Muslims Institutions of Learning in Eleventh-Century Baghdad", Bulletin of the School of Oriental and African Studies, XXIV pp. I-56.

MAKDISI, G., (1970): "Madrasa and University in the Middles Ages", Studia Islamica. 32, pp. 255-264.

MAKDISI, G. (1973):《The Madrasa in Spain: some remarks»), Mélanges Roger Le Tourneau Revue de I'Occident musulman et de la Meditarranée 15-16, pp. 153-158.

MALPICA CUELLO, A. (2000): Granada, ciudad islámica: mitos y realidades. Granada.

MALPICA,A. (2007):"La expansión urbana de la Granada nazarí y la acción de los reyes granadinos" en SER QUIIANO, G. del y MARTÍN VISO, I, (ed.), Espacios de poder y formas sociales en la Edad Media. Estudios dedicados a Ángel Barrios, Salamanca, pp. I33- 154.

MALPICA, A. et al., (2007): "Intervención arqueológica de apoyo a la restauración del Palacio de la Madraza, Granada (2006-2007)", A.A.A 2007 (En prensa).

MARÍN, M. (199|): "Ciencia, enseñanza y cultura en la ciudad islámica", en Simposio Internacional sobre la ciudad islámica, Zaragoza, pp. | | 3-133.

MARTÍNEZ ENAMORADO, V. (1998): Epigrafía y poder inscripciones árabes de la Madrasa al-Ŷadida de Ceuta, Ceuta.

MARTÍNEZ ENAMORADO, V. (2002): "La madrasa alYadīda de Ceuta en el contexto del Islam occidental", en V.AA., Actas de las II Jornadas sobre Historia de Ceuta. Ceuta en el Medievo: La ciudad en el universo árabe, Ceuta, pp. 39-58.

MATTEI, L. (2008): "Estudio de la Madraza de Granada a partir del registro arqueológico y de las metodologías utilizadas en la intervención de 2006", @rqueología y territorio. $N^{\circ}$ 5, pp. |8|-192.

MATTEI, L. (2009): “La evolución urbana del entorno de la Madraza Yūsufiyya a través de su intervención arqueológica", Xelb 9 (VI Encontro de Arqueologia do Algarve), pp. 493-505.

PAULA VALLADAR, F. DE, (I890): Guía de Granada, Granada.

PEZZI, E. (1989): El vocabulario de Pedro de Alcalá, Almería.

PEDERSEN, J. [MAKDISI, G.] y HILLENBRAND, R. ( 1985$)$ : S.v «Madrasa» en E.I', V. Leiden, pp. I | |9- I 44.

RODRÍGUEZ GÓMEZ, M.D. (2000): Las Riberas Nazarí y del Magreb (siglos XIII-XV): intercambios económicos y culturales, Granada.

RUBIERA MATA, Ma. J. (1970) "Datos sobre una "madrasa" en Málaga anterior a la nașri"', al-Andalus. XXXV, pp. 223-226.

RUBIERA MATA, Ma. J. (1994): Ibn al-Ŷayyāb, el otro poeta de la Alhambra, Granada. 
SARR MARROCO, B. (2007): "La Granada zirí: una aproximación a través de las fuentes escritas, arqueológicas e historiográficas", @rqueología y territorio. № 4, pp. 165-180.

SARR MARROCO, B. y REYES MARTíNEZ, E. (2006): "Intervención arqueológica de apoyo a la restauración y consolidación del torreón sureste de la Alcazaba de Guadix (Granada, 2005)", Arqueología y territorio medieval. 13.2., pp. 127-144.

SECO DE LUCENA PAREDES, L. (1956): "El Hāŷib Riḍwān, la madraza de Granada y las murallas del Albayzín", al-Andalus. XXI, pp. 285-296.

SECO DE LUCENA PAREDES, L. (1970): "Notas de Arqueología Granadina", Cuadernos de la Alhambra n 6. pp. 5I-68.

SECO DE LUCENA PAREDES, L. (1975): La Granada nazarí del siglo XV, Granada.

SHATZMILLER, M. (1976) : "Les premiers mérinides et le milieu religieux de Fès : I'introduction des medersas", Studia Islamica. XLIII, pp. I09- I I8.
TALAS, A. (1939): La madrasa Nizamiyya et son histoire, París.

TERRASSE, H. (1927): Médersas du Maroc, París.

TORRES DELGADO, C. (1974) El antiguo reino nazarí de Granada (I 232-1 340), Granada.

TORRES DELGADO, C. (1997) El Reino Nazarí de Granada (I 482-1 492): Muerte o resurrección?, Granada.

VIDAL CASTRO, F. (1995): "Al-Andalus y Marruecos en la Baja Edad Media (ss. XI-XV): Una historia compartida y paralela" en El zoco. Vida económica y artes tradicionales en al-Andalus y Marruecos. Granada, pp. 17-28.

VIDAL CASTRO, F. (2004): "Nazaríes y meriníes, caminos entrecruzados: al-Andalus y el Magreb al-Aqșà («Marruecos»), siglos XIII-XV"' en BENEITO ARIAS, P.y ROLDÁN CASTRO, F (coords.), Al-Andalus y el norte de África: relaciones e influencias, Sevilla, pp. 27I-305.

VIGUERA MOLINS, Ma . I (coord.), (2000): El reino nazarí de Granada (I 232-I 492): política, instituciones, espacio y economía, Colección de Historia de España de R. Menéndez Pidal Vol. 8/3, Madrid, 2000. 


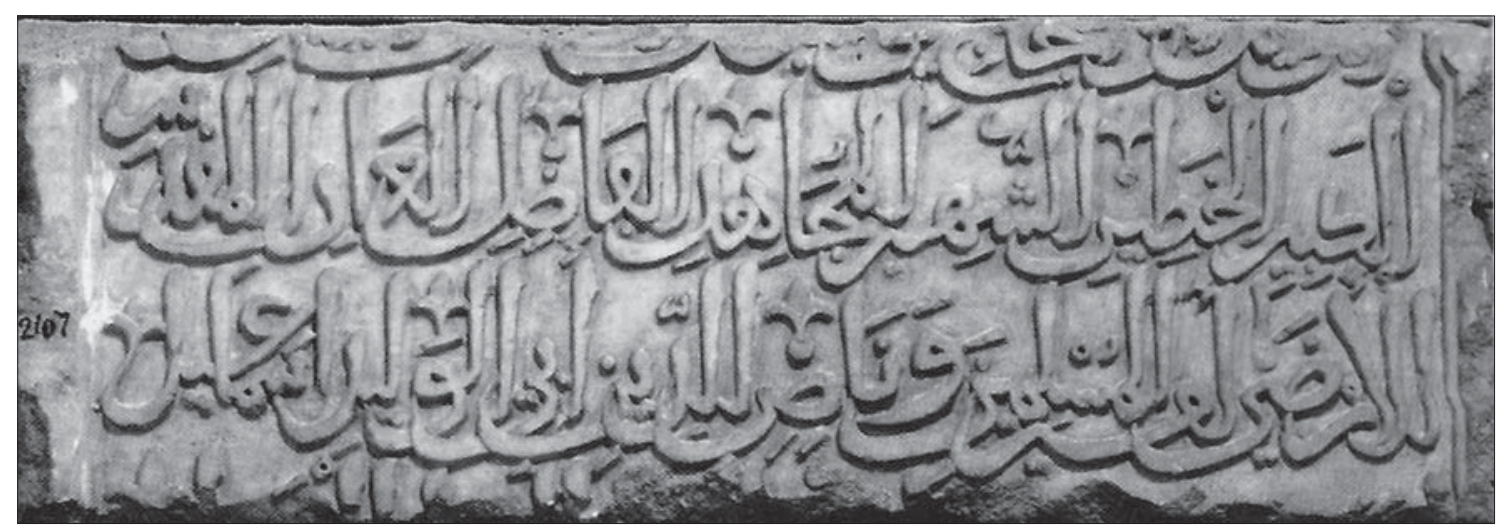

Lám. I. Fragmento de la Portada (Museo Arqueológico y Etnológico de Granada), Inscripción fundacional (CRUZ et alii, 2007: 142).

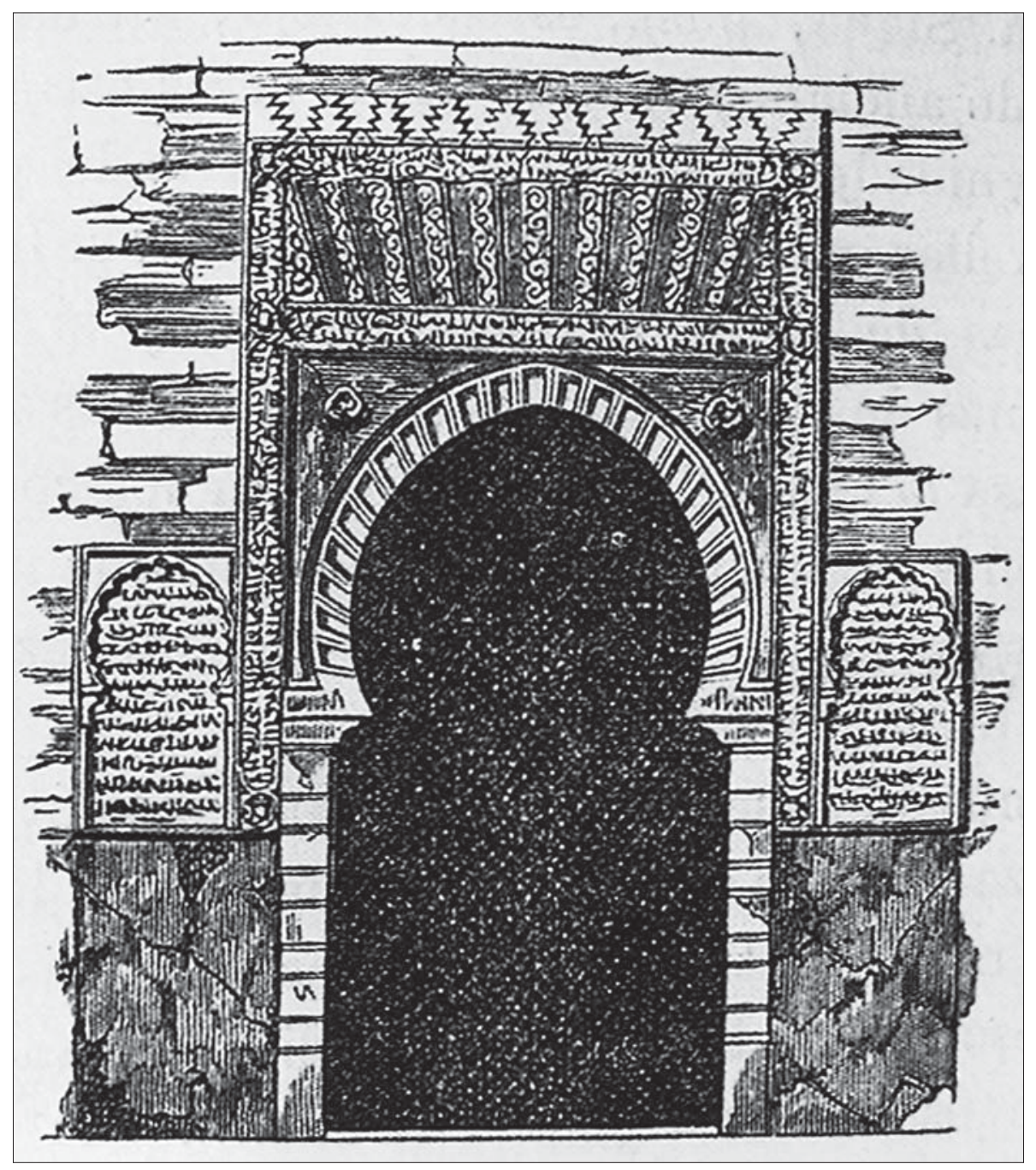

Lám. 2. Restitución de la Portada original, según Rafael Contreras (CRUZ et alii, 2007: 140). 


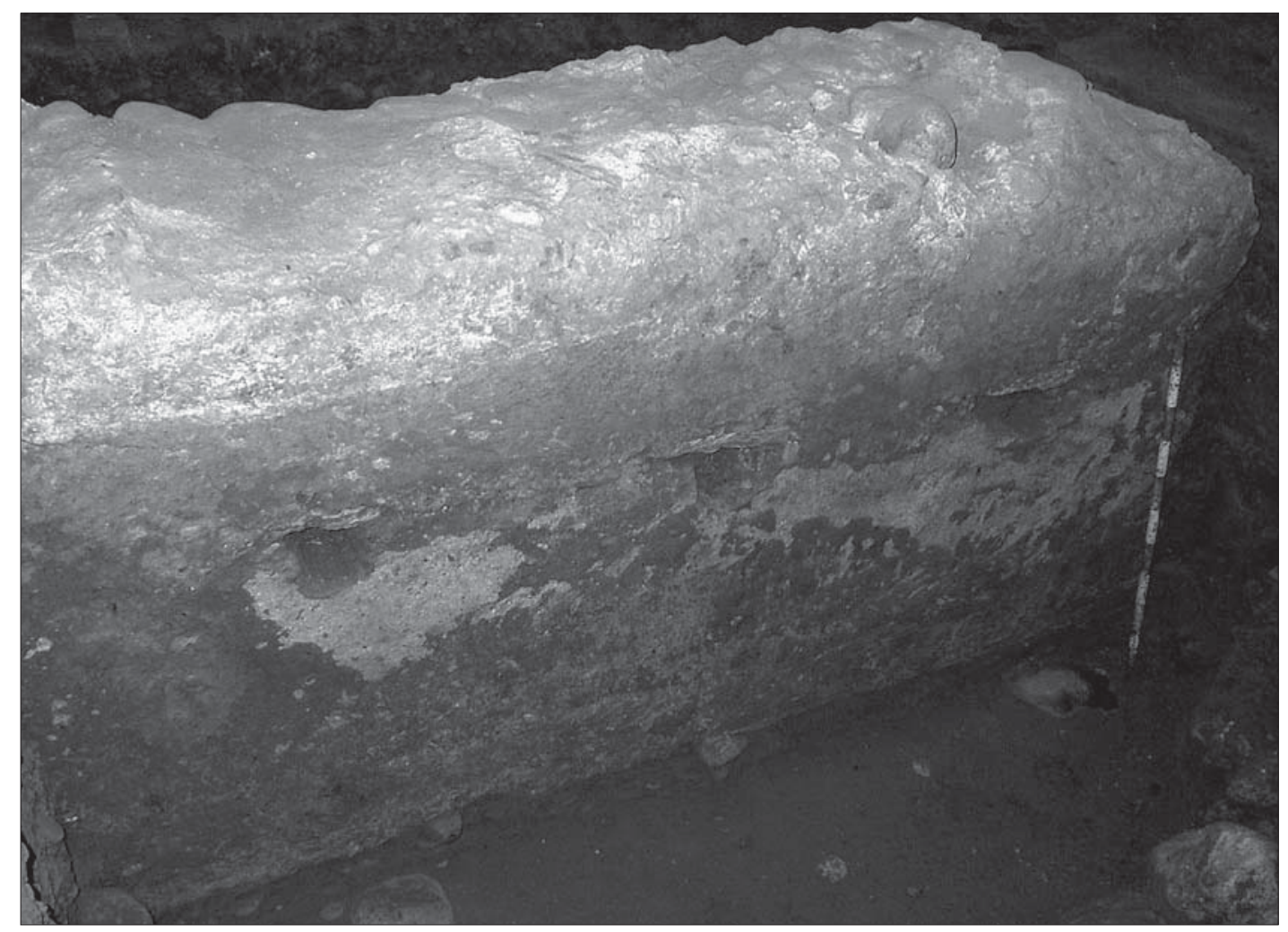

Lám. 3. Muro de tapial de calicanto del recinto residencial zirí.

Lám. 4. Jamba y umbral de la puerta zirí.

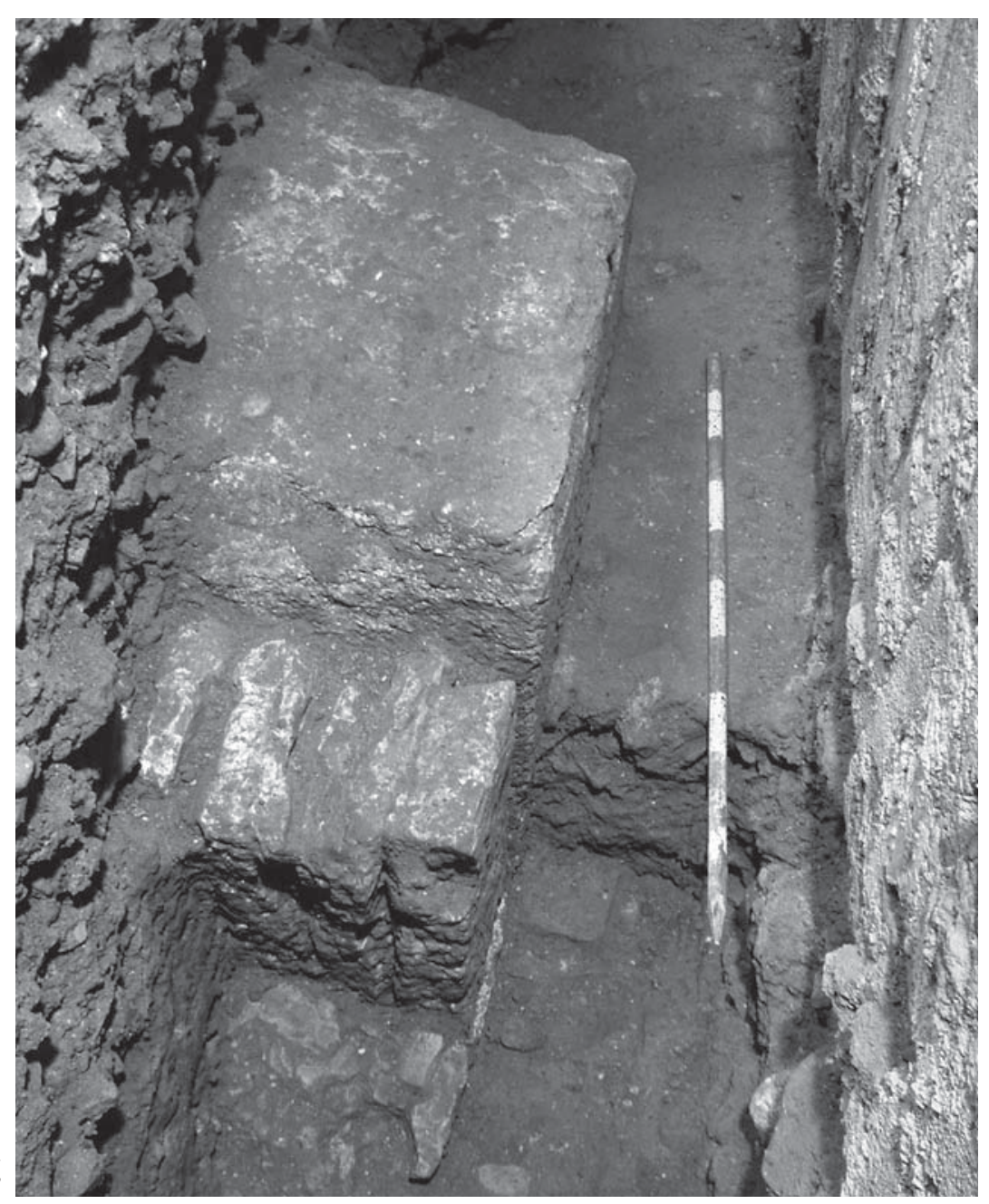




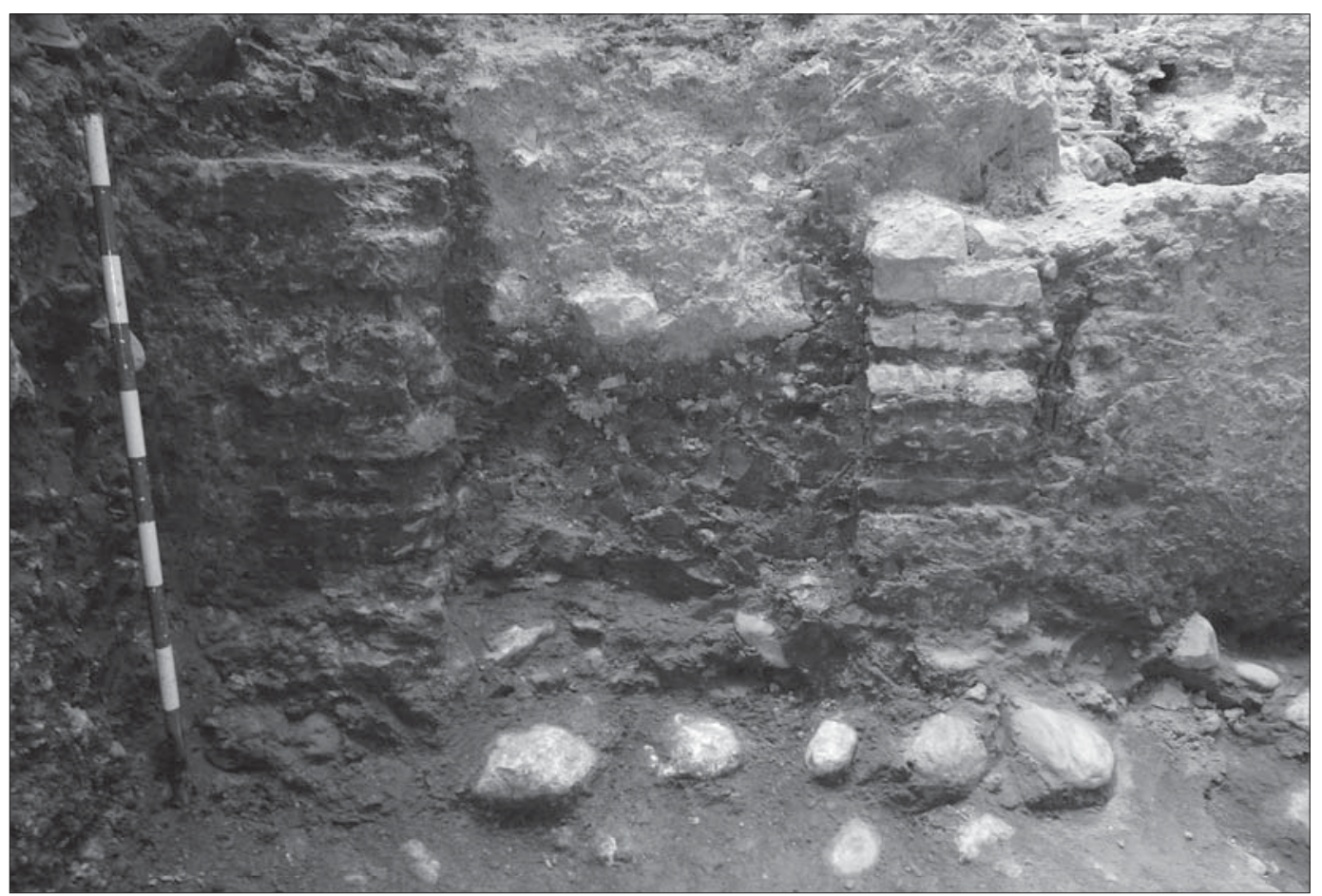

Lám. 5.

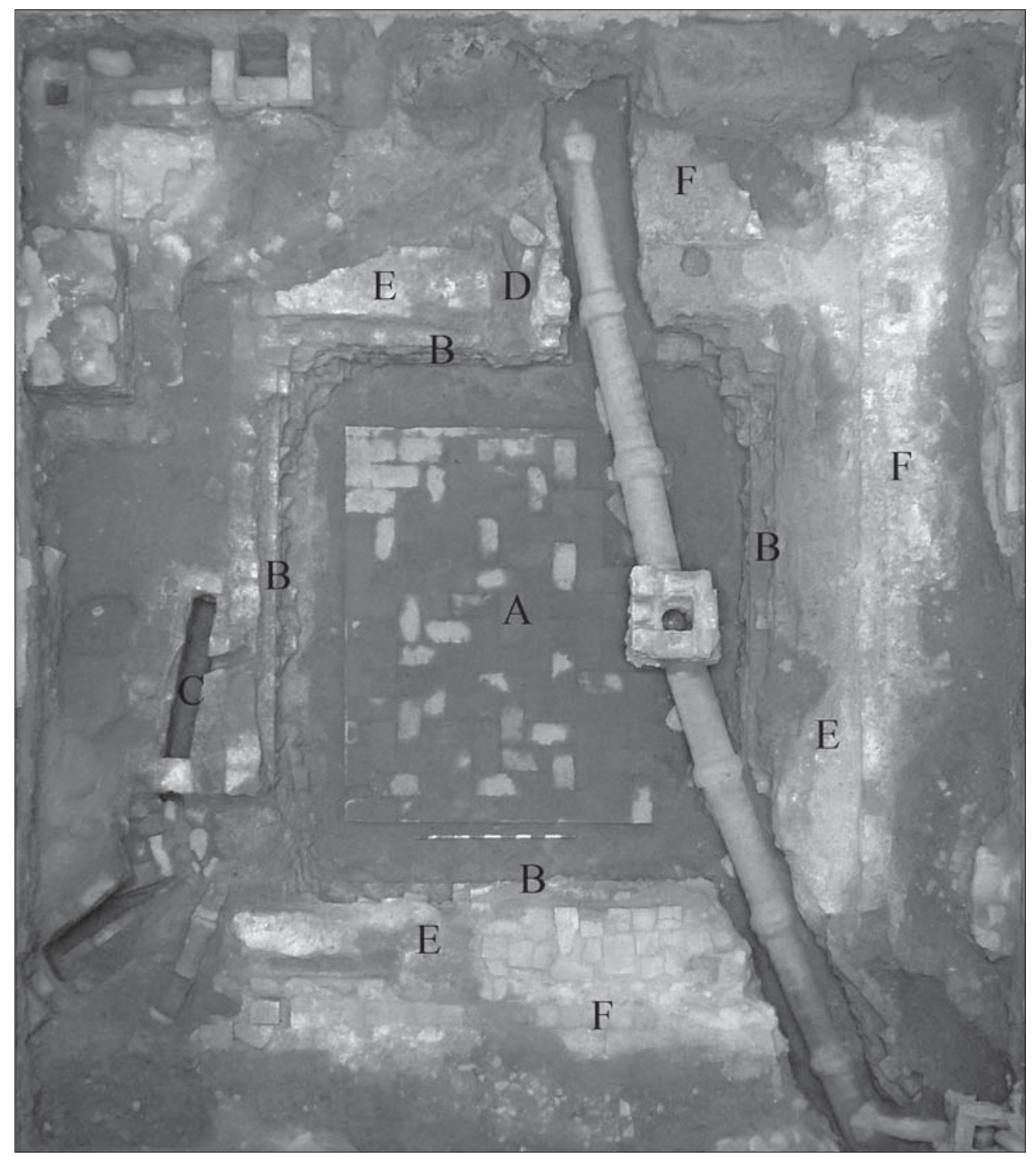

Puerta ziri

Lám. 6. Alberca

de la madraza

Yüsufiyya. A) Suelo

B) Paredes de ladrillo C) Rebosadero D) Entrada del agua E) Andén interior F) Andén exterior. 


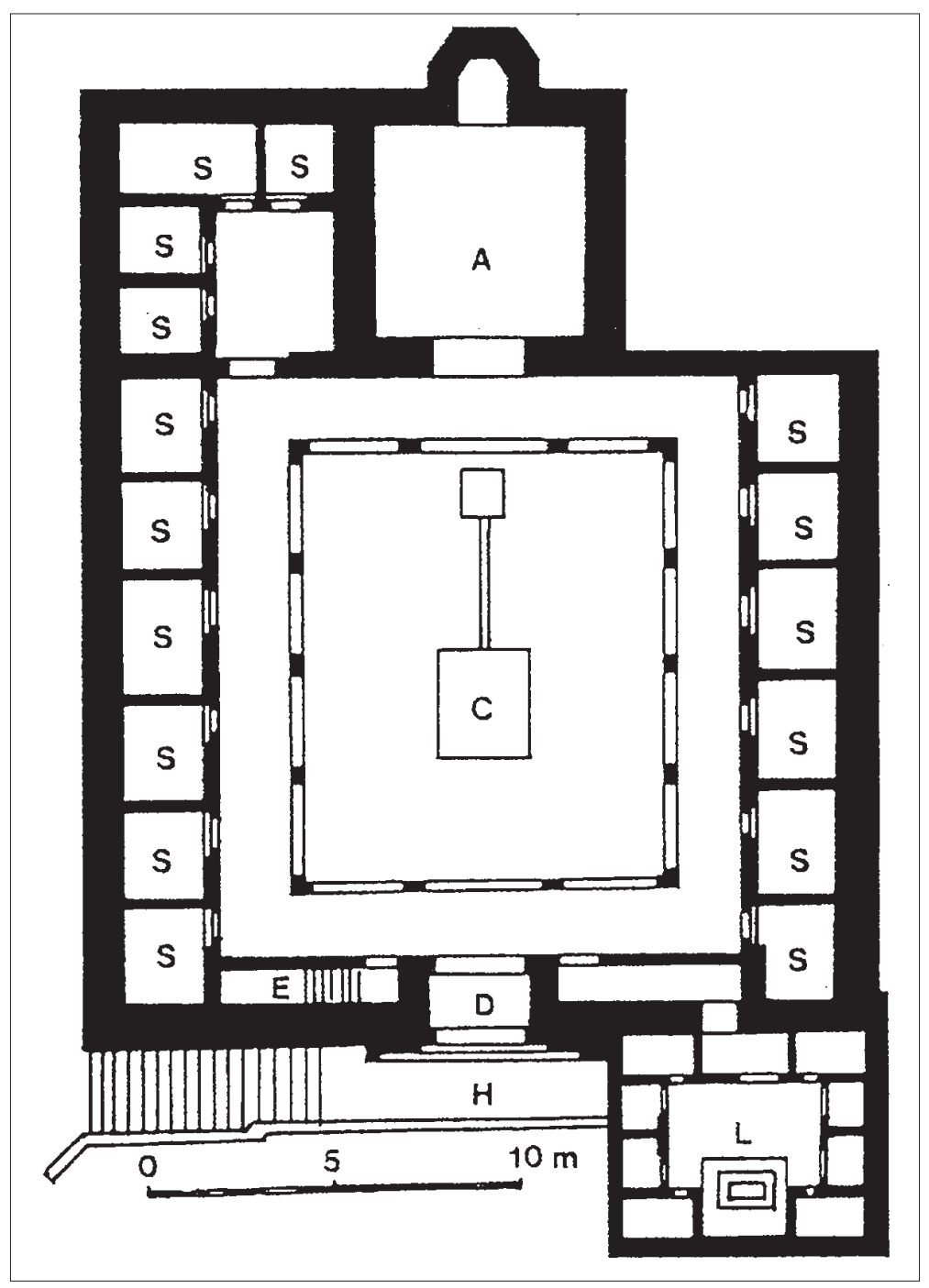

Lám. 7. Planta madrasa al-

'Ubbād de Tremecén (GOLVIN, 1995:203).

Lám. 8. Planta de la madrasa al-'Atțārīn de Fes (GOLVIN, 1995: 230)

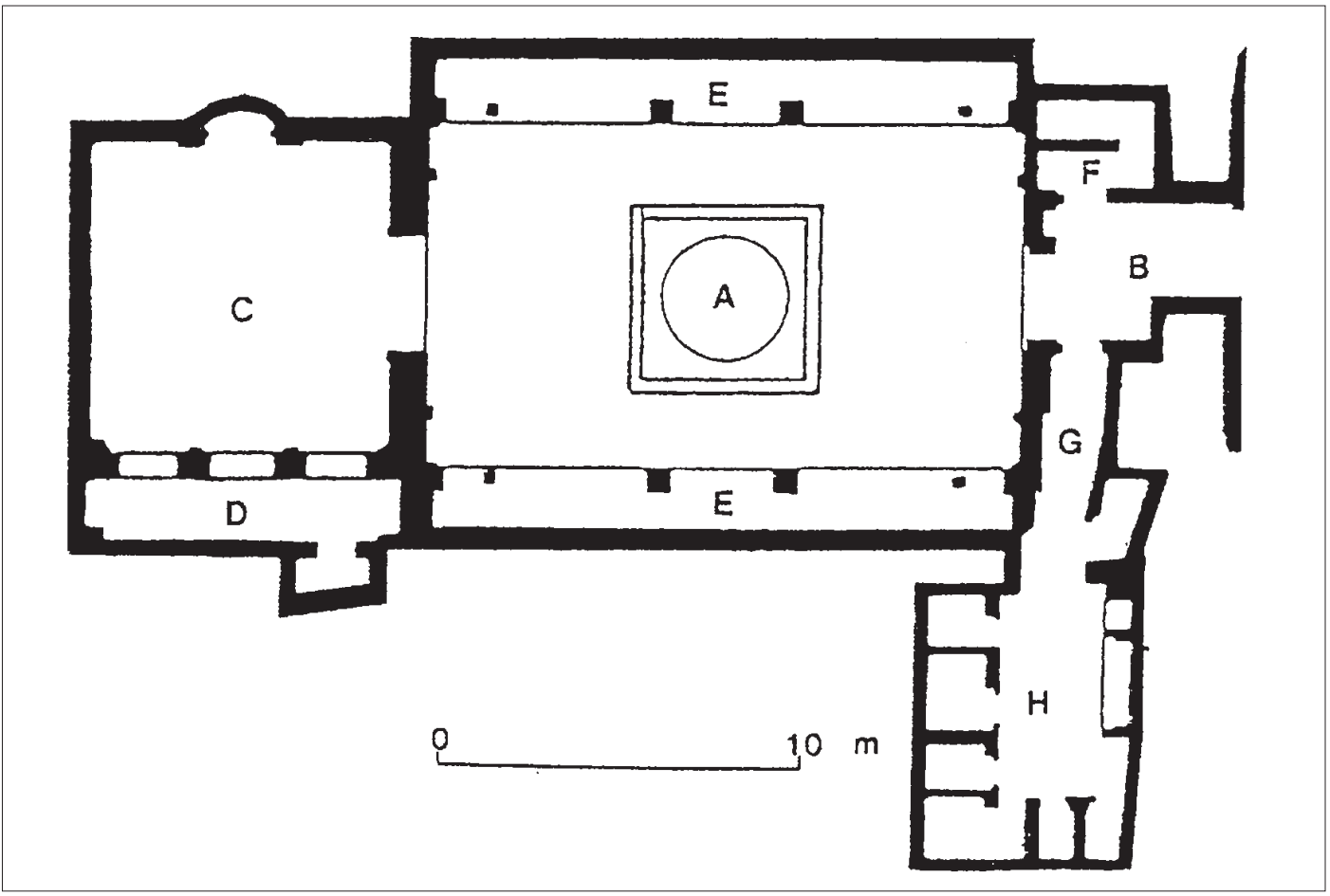




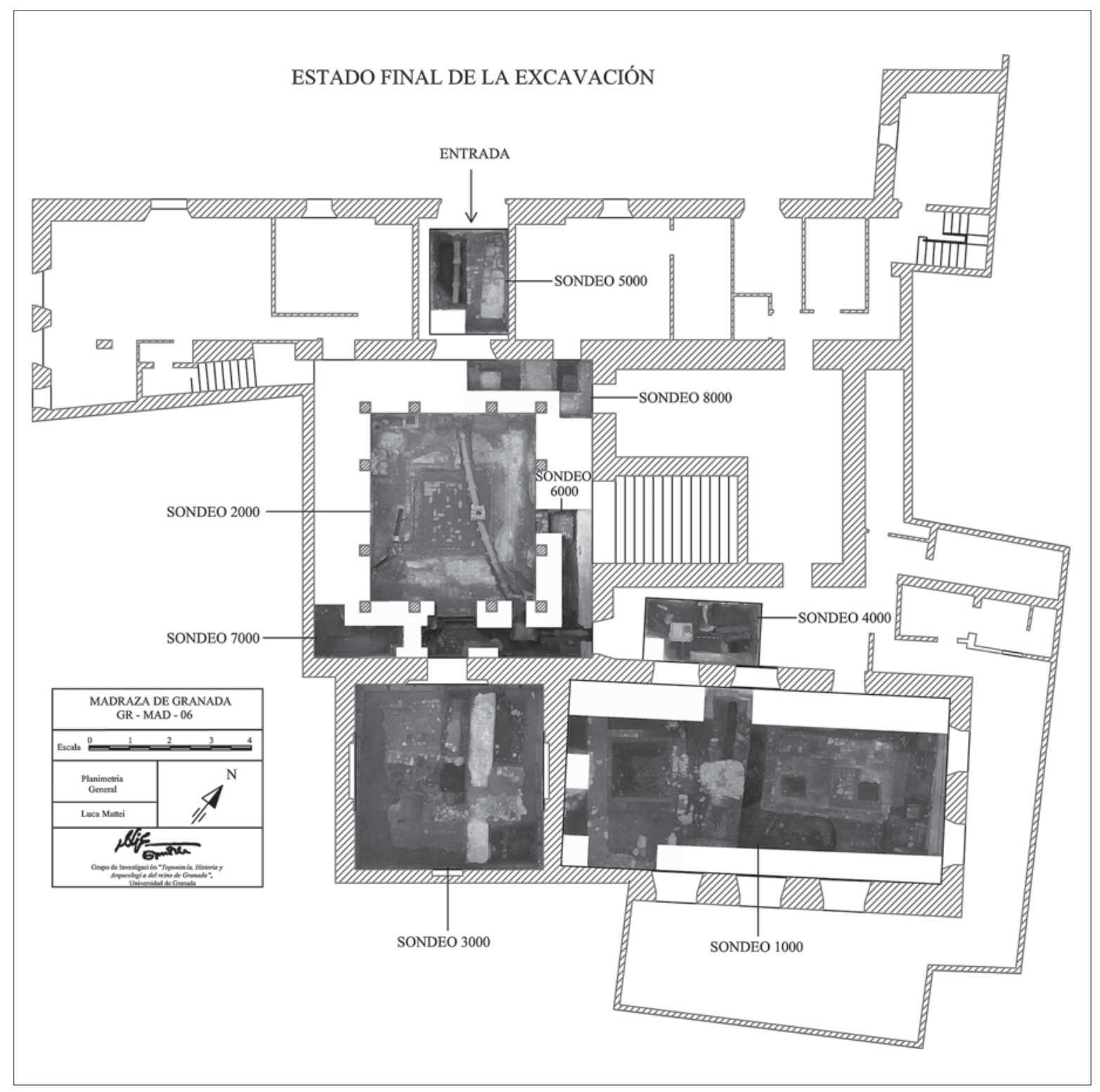

Fig. I. Estado final de la excavación de 2006-07. 


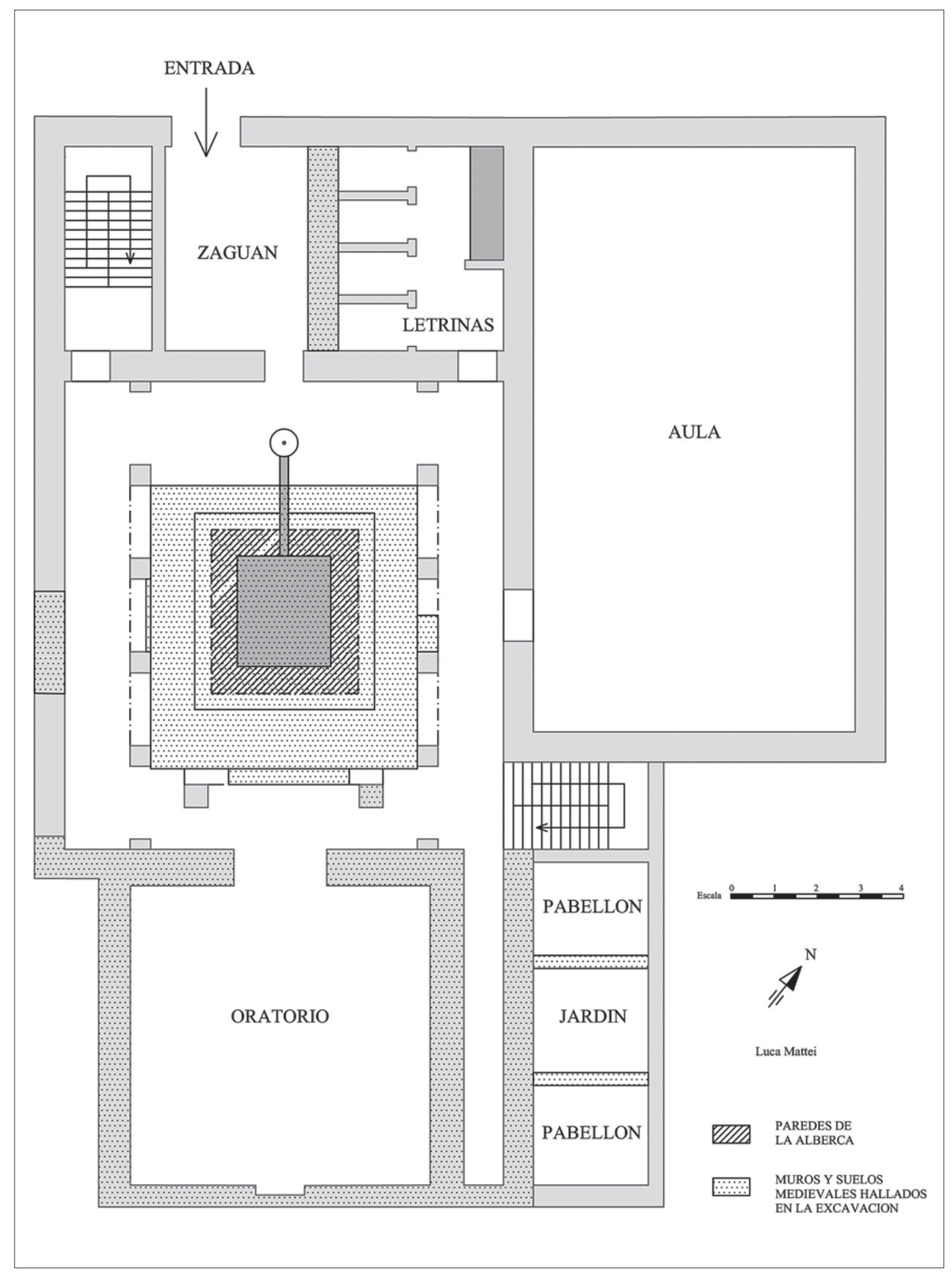

Fig. 2. Hallazgos de la última intervención sobre hipotética reconstrucción de la madraza. 